\title{
GAMBARAN KARAKTERISTIK IBU DAN ANAK TERHADAP KEJADIAN GIZI KURANG PADA ANAK BALITA DI DESA SUKAWATI GIANYAR TAHUN 2014
}

\author{
Parivindaraj Sundaraj \\ Program Studi Pendidikan Dokter Fakultas Kedokteran Universitas Udayana
}

\section{ABSTRAK}

Latar Belakang: Masalah gizi masih merupakan masalah kesehatan utama masyarakat Indonesia. Terdapat kecenderungan peningkatan angka kejadian gizi kurang dan gizi buruk tiap tahunnya, khususnya di wilayah kerja UPT Kesmas Sukawati I.

Tujuan Penelitian: Mengetahui gambaran faktor risiko terhadap kejadian gizi kurang pada anak balita di Desa Sukawati Gianyar.

Metod: Penelitian dilaksanakan pada bulan November-Desember 2014 dengan metode deskriptif cross-sectional. Subyek penelitian adalah anak balita di Desa SukawatiGianyar yang terdiri dari 50 orang. Data didapatkan dengan pengukuran langsung antropometri anak balita dan wawancara terstruktur kepada ibu balita dengan menggunakan bantuan kuesioner. Analisis data dilakukan secara deskriptif dan hasil disajikan dalam bentuk tabel dan naratif.

Hasil: Hasil penelitian menunjukkan bahwa kejadian gizi kurang berdasarkan BB/U pada anak balita di Desa Sukawati Gianyar sebesar $12 \%$. Sebanyak $96 \%$ balita dengan berat badan lahir normal, $62 \%$ balita yang tidak mendapatkan ASI eksklusif, 30\% balita dengan asupan nutrisi kurang, $26 \%$ balita yang memiliki ibu dengan tingkat pendidikan rendah, $64 \%$ balita dengan ibu yang bekerja, $48 \%$ balita dengan pendapatan keluarga rendah, serta sebanyak $52 \%$ balita memiliki ibu dengan pengetahuan terhadap gizi yang kurang.

Simpulan: Faktor risiko yang cenderung terjadi pada anak balita yang berstatus gizi kurang yakni tidak mendapat ASI eksklusif selama 6 bulan, asupan nutrisi yang kurang, pendidikan ibu yang rendah, balita yang memiliki ibu bekerja, serta tingkat pengetahuan ibu tentang gizi yang rendah.

Kata kunci: Gizi kurang, Faktor risiko, Balita, ASI eksklusif

\section{DISTRIBUTION CHARACTERISTICS OF MOTHER AND CHILD TOWARDS INCIDENCE OF MALNUTRITION IN CHILDREN UNDER 5 YEARS OLD AT SUKAWATI VILLAGE, GIANYAR 2014}

\section{ABSTRACT}

Background: Malnutrition is one of the leading health problems among Indonesians. The incidence of malnutrition and poor nutrition increases each year, especially in the province UPT Kesmas Sukawati I.

Aim: This study aims to identify risk factors involved in the incidence of malnutrition in children under 5 years old in Sukawati Village, Gianyar.

Method of Study: Study was conducted between November - December 2014 using descriptive cross sectional study method. Subject of study are children under 5 years old in Sukawati Village, Gianyar consisting of 50 samples. Data was obtained through direct anthropometry measurements of children under 5 and interview of mothers with toddlers through questionnaire. Data analysis was done descriptively and presented in tables and narrative.

Result: Malnutrition according to weight/age in children under 5 years in Sukawati Village is $12 \%$. $96 \%$ of children under 5 years with normal birth weight, $62 \%$ of children under 5 years without Exclusive breastfeeding, $30 \%$ of children under 5 years with poor diet intake, $26 \%$ of children below 5 years with low educated mothers, $64 \%$ of children below 5 years with working mothers, $48 \%$ of children below 5 years with low income families, and $52 \%$ of children below 5 years with mothers lacking knowledge in nutrition. 
Conclusion: Risk factors in children under 5 years with malnourished state are due to absence of exclusive breastfeeding for 6 months, poor diet intake, low educated mothers, working mothers, and mothers lacking knowledge in nutrition.

Keywords: malnutrition, risk factors, children under 5 years, exclusive breastfeeding

\section{PENDAHULUAN}

\section{A. Latar Belakang}

Malnutrisi merupakan suatu kondisi medis yang disebabkan oleh asupan yang tidak mencukupi. Malnutrisi seringdikaitkan dengan keadaan gizi kurang akibatkurangnya konsumsi makanan,penyerapan buruk, atau kehilangan zat gizi secara berlebihan. Namun, istilah malnutrisijuga mencakup keadaan gizi berlebihan. Seseorang mengalami malnutrisi bila jumlah, jenis, atau kualitas yang memadai dari zat gizi yang mencakup diet yang tidak sehat dikonsumsi untuk jangka waktu yang cukup lama. ${ }^{5}$

Kondisi malnutrisi merupakan penyebab primer morbiditas dan mortalitas anak balita di negara berkembang. Hal ini merupakan masalah kesehatan utama dan penyebab kematian anak terbesar. Berdasarkan data dari WHO 2012, prevalensi malnutrisi pada anak di bawah umur lima tahun dari tahun 2005-2011 di dunia masih tinggi yaitu 16,2\%. Tingginya tingkat gizi kurang pada anak menjadi tantangan utama untuk ketahanan hidup dan perkembangan anak., Selain gizi kurang, diperkirakan sekitar 40 juta (6\%) pada balita memiliki gizi lebih dengan berat badan untuk tinggi badan melebihi dari dua standar deviasi dari nilai median standar pertumbuhan anak. ${ }^{23}$

Di Indonesia, masalah gizi masih merupakan masalah kesehatan masyarakat yang utama. Dinas Kesehatan Republik Indonesia tahun 2005 menunjukkan status gizi kurang sampai gizi buruk di Indonesia mencapai 28\%, 18, 4\% pada 2007. Data Riskesdas pada 2010 menunjukan prevalensi balita mengalami gizi kurang-buruk secara nasional adalah 17,9\% dan di tahun 2013 meningkat menjadi 19,6\%. Meskipun kejadian gizi kurang-buruk pada anak balita berfluktuasi dari tahun 2005-2013, namun angka tersebut masih jauh dari target Millenium Development Goals 2015 dimana angka kekurangan gizi diharapkan mencapai kurang dari 15,5\%. Berdasarkan data Riskesdas 2013, prevalensi anak balita yang mengalami gizi buruk secara nasional adalah 5,7 \%, gizi kurang 13,9\%, dan gizi lebih $11,9 \%$. Jika dibandingkan dengan status gizi pada anak balita di provinsi Bali cenderung lebih baik, terlihat dari data prevalensi status gizi yaitu gizi buruk $1,7 \%$, gizi kurang $9,2 \%$ dan gizi lebih $8 \%$. Berdasarkan tinggi badan dibandingkan umur (TB/U), sekitar $14 \%$ balita di Bali masih tergolong sangat pendek dan 15, 3\% pendek. Sedangkan berdasarkan berat badan dibandingkan tinggi badan (BB/TB), sekitar 5,2\% anak balita di daerah Bali tergolong sangat kurus, 7,9 \% kurus dan $17,5 \%$ tergolong gemuk. Meskipun dari data didapatkan bahwa kejadian gizi buruk dan gizi kurang di provinsi Bali lebih rendah dari provinsi lain, namun kasus gizi tersebut menjadi hal yang perlu mendapatkan perhatian khusus. ${ }^{6,16}$

Berdasarkan data Laporan Tahunan Puskesmas Sukawati I tahun 2013, terdapat 5513 anak balita, dan semuanya memiliki Kartu Menuju Sehat (KMS). Dari 5513 balita, 97,53\% anak balita bergizi baik, 1,95\% anak balita mengalami gizi kurang, 0,04\% mengalami gizi buruk dan $0,48 \%$ anak balita mengalami gizi lebih.Dibandingkan dengan data bulan Januari-September 2014, didapatkan bahwa 97\% anak balita bergizi baik, 2,4\% balita mengalami gizi kurang, $0,2 \%$ anak balita yang mengalami gizi buruk dan $0,4 \%$ mengalami gizi lebih.Ditemukan adanya kecenderungan peningkatan angka kejadian gizi kurang dan gizi buruk di wilayah kerja UPT Kesmas Sukawati I Gianyar. ${ }^{18}$

Balita merupakan tahap awal pengenalan anak dengan suatu lingkungan sosial di masyarakat umum di luar keluarga. Seorang anak balita sedang mengalami masa tumbuh kembangnya yang relatif pesat. Pada masa ini, proses perubahan fisik, emosi dan sosial anak balita berlangsung cepat. Proses ini dipengaruhi berbagai faktor dari diri anak sendiri dan lingkungan. Dalam hal konsumsi pangan, pada anak balita akan terjadi peralihan dari golongan konsumen pasifmenjadi konsumen aktif sehingga pada usia balita anak sangat rentan terhadap berbagai masalah kesehatan terutama masalah gizi. Apabila anak mengalami gizi kurang dan kekurangan gizi ini berlangsung lama, maka akan berakibat terganggunya pertumbuhan, perkembangan mental, serta sistem imunitas, sehingga anak mudah terserang penyakit dan berakhir pada kematian. ${ }^{25}$

Faktor penyebab langsung terjadinya gizi kurang adalah ketidakseimbangan gizi dalam makanan yang dikonsumsi serta terjangkitnya penyakit infeksi seperti infeksi saluran pernafasan dan infeksi saluran pencernaan. Faktor tidak langsung seperti kesediaan pangan di keluarga, pola pengasuhan anak, serta pelayanan kesehatan yang tidak memadai. Hal tersebut berkaitan dengan tingkat pendidikan, pengetahuan, pendapatan, serta banyaknya anggota keluarga dan faktor sosial budaya. Faktor ibu memegang peranan penting dalam menyediakan dan 
menyajikan makanan yang bergizi dalam keluarga, sehingga berpengaruh terhadap status gizi anak. ${ }^{23}$

Berbagai penelitian mengenai gizi telah dilakukan untuk mencari faktor-faktor yang sangat berpengaruh terhadap status gizi anak balita. Berdasarkan penelitian yang telah dilakukan oleh Permana (2011), faktor yang signifikan berhubungan dengan malnutrisi yaitu keparahan penyakit, usia, tingkat pendidikan ibu, dan pendapatan keluarga. Hasil penelitian Patodo (2012) menunjukkan bahwa semakin besar pendapatan keluarga maka semakin baik status gizi balita, begitu pula sebaliknya. Hasil penelitian Johanis \& Aaltje (2011) menunjukkan anakanak dari tingkat sosial ekonomi yang rendah lebih banyak mengkonsumsi karbohidrat dan kurang mengkonsumsi protein dan lemak.

Berbagai upaya untuk menanggulangi masalah gizi di lingkungan kerja UPT Kesmas Sukawati I Gianyar telah dilakukan, seperti pemberian makanan tambahan tiap tiga bulan pada balita gizi buruk dan gizi kurang. Penyuluhan gizi secara perorangan juga sudah dilakukan setiap satu bulan bersamaan dengan pelaksanaan posyandu. Selain itu, kader setempat melakukan pemantauan pola konsumsi masyarakat keluarga miskin mengenai jenis, jumlah, dan frekuensi makanan yang dikonsumsi. Hal tersebut dilakukan untuk mencegah kurangnya asupan nutrisi akibat faktor ekonomi yang rendah. Namun tampaknya upaya-upaya tersebut belum efektif untuk mengatasi permasalahan gizi pada balita. ${ }^{18}$

Melihat adanya berbagai faktor risiko yang mempengaruhi kecenderungan peningkatan angka kejadian gizi kurang dan gizi buruk di wilayah kerja UPT Kesmas Sukawati I Gianyar serta upaya-upaya yang sudah dilakukan untuk memperbaiki masalah gizi, maka peneliti telah melakukan penelitian mengenai gambaran karakteristik ibu dan anak terhadap kejadian gizi kurang pada anak balita di Desa Sukawati yang merupakan salah satu wilayah kerja UPT Kesmas Sukawati I Gianyar. Hasil penelitian ini diharapkan dapat menjadi dasar untuk pengembangan dan pelaksanaan program-program pencegahan dan penanganan masalah gizi sehingga nantinya dapat mengurangi angka morbiditas dan mortalitas terkait status gizi kurang pada balita di wilayah kerja Puskesmas Sukawati 1 Kabupaten Gianyar.

\section{B. Rumusan Masalah}

Dari latar belakang permasalahan di atas, maka dapat ditarik rumusan masalah yaitu: Bagaimana gambaran karakteristik ibu dan anak terhadap kejadian gizi kurang pada anak balita di Desa Sukawati Gianyar tahun 2014?

\section{Tujuan}

Untuk mengetahui gambaran karakteristik ibu dan anak terhadap kejadian gizi kurang pada anak balita di Desa SukawatiGianyar tahun 2014, faktor risiko pada anak maupun ibu terhadap status gizi anak, meliputi berat badan lahir anak, riwayat ASI eksklusif, asupan nutrisi anak, tingkat pendidikan ibu, pekerjaan ibu, pendapatan keluarga, serta pengetahuan ibu tentang gizi dan kecenderungan status gizi berdasarkan faktor risiko terhadap kejadian gizi kurang pada anak balita di Desa Sukawati Gianyar.

\section{Manfaat}

Adapun manfaat yang diharapkan dapat diperoleh dari penelitian ini adalah memberikan informasi mengenai pentingnya keadaan gizi pada anak balita dan faktorfaktor yang mempengaruhi kejadian gizi kurang serta memberikan masukan kepada petugas kesehatan masyarakat sehingga dapat lebih meningkatkan program penyuluhan tentang gizi anak balita di Desa Sukawati, Gianyar.

\section{TINJAUAN PUSTAKA}

Status gizi merupakan keadaan kesehatan tubuh seseorang yang diakibatkan konsumsi, penyerapan dan penggunaan zat gizi berdasarkan ukuran tertentu.Status gizi normal merupakan ukuran status gizi dimana terdapat keseimbangan antara jumlah energi yang masuk ke dalam tubuh dan energi yang dikeluarkan dari luar tubuh sesuai dengan kebutuhan individu. Status gizi kurang merupakan keadaan gizi dimana jumlah energi yang masuk lebih sedikit dari energi yang dikeluarkan. Status gizi lebih adalah bila jumlah energi yang masuk ke dalam tubuh lebih besar dari jumlah energi yang dikeluarkan. Kelebihan zat gizi disimpan dalam bentuk lemak yang mengakibatkan kegemukan. ${ }^{22}$

Salah satu penilaian status gizi secara langsung yaitu dengan antropometri. Indeks antropometri yang umum digunakan dalam menilai status gizi adalah berat badan menurut umur (BB/U), tinggi badan menurut umur (TB/U), dan berat badan menurut tinggi badan (BB/TB). Sedangkan penilaian status gizi secara langsung salah satunya dengan 24 hours food recall. ${ }^{22}$

Indeks BB/U, standaruntuk menilai pertumbuhan,adalah pengukuran total berat badan yang memberi gambaran tentang massa tubuh, termasuk air, lemak, tulang dan otot. Indeks yang dipakai pada SUSENAS dalam penentuan status gizi balita ialah indeks BB/U. Berat badan adalah parameter antropometri yang sangat labil dan sensitif terhadap perubahan yang mendadak, misalnya penyakit infeksi, menurunnya nafsu makan, atau menurunnya jumlah konsumsimakanan, maka indeks $\mathrm{BB} / \mathrm{U}$ lebih menggambarkan status gizi saat ini. Kelebihan Indeks BB/U adalah lebih mudah dan cepat dimengerti masyarakat umum; baik untuk mengukur status gizi akut atau kronis,sangat sensitif terhadap perubahan-perubahan kecil danmendeteksi kegemukan. Antara kelemahan Indeks BB/U adalah mengakibatkan interpretasi status gizi yang kelirubila 
terdapat edema/ asites; memerlukan data umur yang akurat, terutama untuk anak balita; dan sering terjadi kesalahan dalam pengukuran seperti pengaruh pakaian atau gerakan anak pada saat menimbang. ${ }^{22}$

Tinggi badan merupakan antropometri yang menggambarkan keadaan pertumbuhan skeletal. Pada keadaan normal, tinggi badan tumbuh seiring dengan pertambahan umur. Pertumbuhan tinggi badan tidak seperti berat badan, relatif kurang sensitif terhadap masalah kekurangan gizi dalam waktu yang pendek, maka indeks TB/U menggambarkan status gizi masa lalu dan erat kaitannya dengan status sosial-ekonomi. Keuntungan Indeks TB/U adalah baik untuk menilai status gizi masa lampau, ukuran panjang dapat dibuat sendiri, murah dan mudah dibawa manakala kelemahan Indeks TB/U adalah tinggi badan tidak cepat naik, bahkan tidak mungkin menurun, pengukuran relatif sulit dilakukan karena anak harus berdiri tegak, sehingga diperlukan dua orang atau lebih untuk melakukannya. ${ }^{22}$

Berat badan memiliki hubungan yang linear dengan tinggi badan. Dalam keadaan normal, perkembangan berat badan searah dengan pertumbuhan tinggi badan dengan kecepatan tertentu. Indeks BB/TB berguna untuk mengidentifikasi status gizi saat ini. Keuntungan Indeks BB/TB adalah tidak memerlukan data umur, dapat membedakan proporsi badan (gemuk, normal dan kurus); manakala kelemahan Indeks BB/TB adalah tidak dapat memberikan gambaran apakah anak pendek, cukup tinggi badan atau kelebihan tinggi badan menurut umurnya karena faktor umur tidak dipertimbangkan; dalam praktek sering mengalami kesulitan dalam melakukan pengukuran panjang/ tinggi badan pada kelompok balita; dan membutuhkan dua macam alat ukur serta pengukuran yang relatif lama. ${ }^{22}$

Pada 24-hour recall, subyek mengingat semua jenis dan jumlah panganyang dikonsumsi dalam 24 jam terakhir. Hal ini dipengaruhi daya ingat subyek, keterampilan penanya, dan variasi makanan dari hari ke hari. Dalam menghitung jumlah zat gizi yang dikonsumsi, jenis dan jumlah pangan merupakan hal yang penting. ${ }^{12}$

Antara faktor yang mempengaruhi status gizi anak adalah faktor anak itu sendiri seperti jenis kelamin, berat badan lahir anak, status kesehatan, riwayat imunisasi, riwayat ASI ekslusif dan asupan nutrisi. Antara faktor ibu adalah pengetahuan ibu, tingkat pendidikan ibu, pekerjaan ibu, pendapatan keluarga, pola asuh dan pelayanan kesehatan.

\section{METODE}

\section{A. Jenis Penelitian}

Jenis penelitian ini adalah deskriptif cross-sectional.

\section{B. Tempat dan Waktu Penelitian}

Penelitian ini dilaksanakan di Desa Sukawati, Kecamatan Sukawati, Kabupaten Gianyar. Pengambilan data dilakukan selama NovemberDesember 2014.

\section{Populasi}

Populasi penelitian adalah semua anak balita yang tercatat di Laporan Puskesmas Desa Sukawati, Kabupaten Gianyar.

\section{Sampel \\ i) Besar sampel}

Besar sampel ditentukan berdasarkan rumus Stanley Lameshow:

$\mathrm{n}=\frac{\mathrm{Z \alpha ^{2 } P Q}}{\mathrm{d}^{2}}$

$\mathrm{n}=\left(1,96^{2}\right) \times 0,2 \times(1-0,2)=40$

dimana,

$n$ : besar subjek

$z_{\alpha}$ : sama dengan 1,96 pada confidence interval $95 \%$

$p: 20,8 \%$ (estimasi proporsi anak balita bergizi kurang pada ibu yang bekerja, didapat daripenelitian sebelumnya oleh Palupi 2014)

$q: 1-p$

$d:$ ketepatan absolut yang dipakai (ditetapkan oleh peneliti $=12,5 \%$ )

Jumlah populasi dalam penelitian ini terbatas (kurang dari 10.000), maka jumlah sampel yang dibuat dari perhitungan rumus di atas perlu dikoreksi. Jumlah sampel dengan koreksi dihitung dengan rumus sebagai berikut:

$n \mathrm{k}=\frac{n}{1+n / N}$

$$
n=\frac{40}{1+40 / 5513}
$$

$n=40$

Berdasarkan perhitungan diatas, didapatkan jumlah sampel minimal dalam penelitian ini adalah sebanyak 40. Peneliti menetapkan besar sampel dalam penelitian ini adalah 50 orang.

\section{ii) Metode Pemilihan Sampel Penelitian}

Wilayah kerja UPT Kesmas Sukawati I Gianyar memiliki 6 desa. Sampel dalam penelitian ini dipilih di Desa Sukawati karena kejadian gizi kurang pada balita paling banyak terjadi di Desa Sukawati. Pemilihan sampel diawali dengan pendataan balita yang ada di Desa Sukawati Gianyar. Terdapat 6 banjar di Desa Sukawati dan dipilih 2 banjar yaitu Banjar Gelumpang dan Banjar Tebuana. Banjar tersebut terpilih karena kejadian gizi kurang pada balita paling banyak terjadi di kedua banjar tersebut. Sampling frame pada Banjar Gelumpang sebanyak 152 sampel dan di Banjar Tebuana sebanyak 84 sampel. Setelah itu, dipilih 25 orang balita di masing-masing banjar dengan cara simple random sampling.

\section{iii) Kriteria Inklusi}

a. Anak balita yang berusia 6-59 bulan. 
b. Bertempat tinggal di Desa Sukawati, Kabupaten Gianyar.

\section{iv) Kriteria Eksklusif}

a. Bayi yang berusia kurang dari 6 bulan.

b. Ibu balita yang sudah meninggal maupun pindah alamat.

\section{E. Responden}

Responden dalam penelitian ini adalah ibu balita yang terpilih menjadi sampel penelitian di Desa Sukawati, Gianyar.

\section{F. Variabel Penelitian}

Variabel dalam penelitian ini adalah pendidikan ibu, pekerjaan ibu, pendapatan keluarga, pengetahuan ibu tentang gizi, berat badan lahir anak, riwayat ASI eksklusif, asupan nutrisi anak, serta status gizi anak.

\section{G. Definisi Variabel Operasional}

a. Pendidikan ibu adalah pendidikan formal terakhir yang diikuti ibu hingga tamat. Tingkat pendidikan ibu dibagi menjadi dua kategori yaitu rendah (tidak sekolah, tamat SD, tamat SMP) dan tinggi (tamatan SMA, universitas).

b. Pekerjaan ibu adalah jenis kegiatan ibu sehari-hari yang menghasilkan uang, dibedakan bekerja dan tidak bekerja.

c. Pendapatan keluarga adalah pendapatan total keluarga dalam sebulan, diklasifikasikanmenjadi di bawah UMR (<Rp 1.543.000) dan di atas atau sama dengan UMR ( $\geq$ Rp 1.543.000).

d. Pengetahuan ibu tentang gizi didapat dari wawancara terstruktur yang berisi pertanyaan untuk mengidentifikasi pengetahuan ibu tentang gizi pada balita, kemudian diberi skor masingmasing jawaban yang dipilih responden, diberi nilai 1 bila jawaban benar serta nilai 0 bila salah. Jawaban benar bila sesuai teori dan begitu pula sebaliknya. Tingkat pengetahuan dibagi menjadi dua kategori, yaitu kurang (bila skor $<70 \%$ ) dan cukup (bila skor $\geq 70 \%$ ).

e. Berat badan anak ketika lahir didapat dengan wawancara langsung dengan responden. Kemudian dikategorikan menjadi berat badan lahir rendah (<2500 gram), normal (2500-4000 gram), dan lebih (>4000 gram).

f. Riwayat ASI ekslusif adalah riwayat anak mendapatkan ASI secara ekslusif tanpa mendapatkan makanan lain saat berusia 0 bulan sampai dengan 6 bulan, dikategorikan menjadi ya dan tidak.

g. Asupan nutrisi anak adalah jumlah dan jenis makanan yang dikonsumsi oleh anak dalam 24 jam terakhir menggunakan kuisioner yang dicatat menggunakan ukuran rumah tangga (URT) seperti sendok nasi, sendok makan, potong kecil, sedang, besar, untuk sayur dan cairan dihitung per gelas belimbing dan diubah ke satuan kalori menggunakan aplikasi Nutriclin 3 yang mengacu pada Daftar Komposisi Bahan Makanan (DKBM)
Dinas Kesehatan, kementrian Kesehatan RI. Jumlah energi dibandingkan dengan Angka Kecukupan Gizi (AKG) menurut kelompok umur sesuai Widya Pangan dan Gizi Indonesia 2013. Asupan nutrisi pada anak balita dikategorikan menjadi kurang (total kalori harian $<80 \% A K G$ ), cukup (total kalori harian $80-100 \% A K G$ ), lebih (total kalori harian $>100 \%$ AKG).

h. Status gizi anak didefinisikan sebagai keadaan gizi anak berdasarkan ukuran antropometrik, yakni perbandingan berat badan dengan umur (BB-U), tinggi badan dengan umur (TB-U), dan berat badan dengan tinggi badan (BB-TB).

i. Berat badan anak adalah ukuran berat tubuh menggunakan alat penimbang berat dengan satuan kilogram (kg).

j. Tinggi badan anak adalah ukuran jarak tubuh dari ujung kepala hingga tumit dalam posisi berdiri tegak. Tinggi badan diukur dengan meteran pengukur dengan satuan sentimeter $(\mathrm{cm})$.

k. Umur anak dan umur ibu ditentukan dari hasil perhitungan tanggal lahir dengan tanggal pengambilan data. Tanggal lahir didapat dari wawancara langsung dengan responden.

I. Jenis kelamin anak dikategorikan menjadi laki-laki atau perempuan.

\section{H. Alat dan Cara Pengumpulan Data}

a. Pengukuran langsung berat badan (BB) terhadap semua subyek penelitian oleh pengumpul data dengan menggunakan timbangan berat badan tipe Bathroom Scale dan timbangan berat badan bayi, dalam satuan kilogram (kg) dengan ketelitian $0,1 \mathrm{~kg}$. Pengukuran tinggi badan (TB) dengan menggunakan microtoise dan tape measure, dalam satuan sentimeter $(\mathrm{cm})$ dengan ketelitian $0,1 \mathrm{~cm}$

b. Pengisian kuisioner yang dilakukan oleh pengumpul data dengan cara menanyakan langsung kepada responden.

\section{Analisis Data}

Analisis yang dilakukan meliputi distribusi frekuensi, rerata dan standar deviasi masing masing variabel serta dilakukan analisis univariat maupun bivariat. Kemudian disajikan dalam bentuk naratif atau tabel. Seluruh data yang diperoleh dianalisis menggunakan perangkat lunak SPSS 17.0.

\section{HASIL}

\section{A. Karakteristik Demografi Subjek Penelitian}

Penelitian ini dilakukan terhadap anak balita (usia 6-59 bulan) di Desa Sukawati di Banjar Gelumpang dan Banjar Tebuana yang termasuk sebagai wilayah kerja UPT Kesmas Sukawati I Gianyar. Jumlah responden yang memenuhi kriteria inklusi dan eksklusi sebanyak 50 orang. Karakteristik demografi subjek penelitian dijabarkan antara lain usia ibu saat ini, usia anak, serta jenis kelamin anak. Sebagian besar 
responden berusia $25-35$ tahun (60\%) dengan rerata usia yaitu 33 tahun. Sedangkan rerata usia anak yang menjadi subjek penelitian yaitu 29 bulan dan sebagian besar berjenis kelamin laki-laki (56\%) (Tabel 1 dan 2).

Tabel 1. Persentase Subjek Penelitian Berdasarkan Usia Ibu Saat Ini dan JenisKelamin Anak

\begin{tabular}{ccc}
\hline Karakteristik & Jumlah & Persentase (\%) \\
\hline Usia Ibu Saat Ini & & \\
$<25$ tahun & 4 & 8,0 \\
$25-35$ tahun & 30 & 60,0 \\
$>35$ tahun & 16 & 32,0 \\
Jenis Kelamin Anak & & \\
Laki-laki & 28 & 56,0 \\
Perempuan & 22 & 44,0 \\
\hline Total & 50 & 100 \\
\hline
\end{tabular}

Tabel 2. Distribusi Rerata Karakteristik Subjek Berdasarkan Usia Ibu Saat Ini dan Usia Anak $(n=50)$

\section{B.Gambaran Faktor Risiko Anak Balita}

Berdasarkan hasil penelitian yang meliputi 50 subjek anak balita, didapatkan hampir seluruhnya lahir dengan berat badan normal yakni berjumlah 48 anak (96\%), 2 anak lahir dengan berat badan lebih (4\%), dan tidak ditemukan anak yang memiliki berat badan lahir rendah. Selain itu, sekitar $62 \%$ anak balita yang menjadi subjek tidak mendapatkan ASI eksklusif dan sisanya mendapatkan ASI eksklusif. ASI eksklusif yang dimaksud adalah pemberian ASI saja sampai umur anak 6 bulan tanpa tambahan makanan apapun. Berdasarkan jumlah asupan nutrisi yang didapatkan oleh anak balita dalam sehari, sekitar 30\% anak mendapatkan asupan nutrisi yang kurang, dan sebagian besar anak mendapatkan asupan nutrisi yang cukup (64\%) (Tabel 3).

Tabel 3. Distribusi Anak Balita Berdasarkan Berat Badan Lahir, Riwayat ASI Eksklusif, serta Asupan Nutrisi di Desa Sukawati Gianyar $(n=50)$

\begin{tabular}{ccc}
\hline Variabel Independen & Jumlah & Persentase (\%) \\
\hline Berat Badan Lahir Anak & & \\
Normal & 48 & 96,0 \\
Lebih & 2 & 4,0 \\
Riwayat ASI Eksklusif & & \\
Tidak & 31 & 62,0 \\
Ya & 19 & 38,0 \\
Asupan Nutrisi & & \\
Kurang & 15 & 30,0 \\
Cukup & 32 & 64,0 \\
Lebih & 3 & 6,0 \\
\hline Total & 50 & 100 \\
\hline
\end{tabular}

\section{Gambaran Faktor Risiko Ibu}

Hasil penelitian menunjukkan dari 50 responden didapatkan ibu dengan tingkat pendidikan rendah sebesar $26 \%$ dan pendidikan tinggi sebesar 74 $\%$, dimana terbanyak adalah ibu dengan pendidikan terakhir SMA/sederajat yakni sebanyak 32 orang (64\%). Berdasarkan pekerjaan ibu, ibu yang bekerja sebanyak 32 orang (64\%) dengan jenis pekerjaan yang beraneka ragam seperti pedagang, buruh, pengrajin, guru, maupun pegawai swasta. Bila dilihat dari pendapatan keluarga, sebanyak $52 \%$ memiliki pendapatan keluarga lebih dari UMR Kabupaten Gianyar Propinsi Bali tahun 2014 yaitu Rp 1.543.000. Sedangkan sisanya (48\%) masih memiliki pendapatan kurang dari UMR (Tabel 4).

Tabel 4. Distribusi Responden Berdasarkan Tingkat Pendidikan Ibu, Pekerjaan Ibu, Pendapatan Keluarga, serta Pengetahuan Ibu Tentang Gizi di Desa Sukawati Gianyar $(n=50)$

\begin{tabular}{lc}
\hline Karakteristik & Rerata \pm SD \\
\hline Usia Ibu Saat Ini (tahun) & $32,48 \pm 5,45$ \\
Usia Anak (bulan) & $29,08 \pm 15,74$
\end{tabular}

\begin{tabular}{lll}
\hline Variabel Independen & Jumlah & Persentase (\%) \\
\hline $\begin{array}{l}\text { Tingkat Pendidikan Ibu } \\
\text { Rendah }\end{array}$ & 13 & 26,0 \\
Tinggi & 37 & 74,0 \\
$\begin{array}{l}\text { Pekerjaan Ibu } \\
\text { Bekerja }\end{array}$ & 32 & 64,0 \\
$\begin{array}{l}\text { Tidak Bekerja } \\
\text { Pendapatan Keluarga }\end{array}$ & 18 & 36,0 \\
$\begin{array}{l}\text { Rp 1.543.000 } \\
\text { Rp 1.543.000 }\end{array}$ & 24 & 48,0 \\
$\begin{array}{l}\text { Pengetahuan Ibu tentang } \\
\text { Gizi }\end{array}$ & 26 & 52,0 \\
Kurang & 26 & 52,0 \\
Cukup & 24 & 48,0 \\
\hline Total & & \\
\hline & 50 & 100 \\
\hline
\end{tabular}

\section{Gambaran Status Gizi Anak}

Pengukuran antropometri sampel mendapatkan hasil rerata berat badan sampel $12,3 \mathrm{~kg}$ dengan berat terendah $7 \mathrm{~kg}$ dan berat tertinggi $26 \mathrm{~kg}$. Didapatkan juga rerata tinggi badan sampel $88,4 \mathrm{~cm}$ dengan tinggi badan tertinggi adalah $117 \mathrm{~cm}$ dan terendah $55 \mathrm{~cm}$. Distribusi status gizi menurut BB/U menunjukkan sebagian besar (82\%) berada pada kategori status gizi baik, $12 \%$ termasuk status gizi kurang, $6 \%$ termasuk kategori gizi lebih (Tabel 5).

Tabel 5. Gambaran Status Gizi Anak Balita Berdasarkan BB/U di Desa Sukawati Gianyar $(n=50)$

\begin{tabular}{ccc}
\hline Status Gizi & Jumlah & $\begin{array}{c}\text { Persentase } \\
(\%)\end{array}$ \\
\hline
\end{tabular}




\begin{tabular}{ccc}
\hline BB/U & & \\
Gizi Kurang & 6 & 12,0 \\
Gizi Baik & 41 & 82,0 \\
Gizi Lebih & 3 & 6,0 \\
\hline Total & 50 & 100 \\
\hline
\end{tabular}

\section{E. Hasil Tabulasi Silang Antara Variabel Status Gizi dengan Variabel Independen}

Tabel 6 di bawah ini menggambarkan distribusi frekuensi status gizi anak balita berdasarkan $\mathrm{BB} / \mathrm{U}$ berdasarkan variabel lainnya. Pada anak-anak dengan asupan nutrisi kurang, sebanyak 33,3\% mengalami gizi kurang, lebih tinggi dibandingkan anak dengan asupan nutrisi cukup yakni sebanyak 3,1\%. Anak dengan asupan nutrisi yang cukup (96,9\%) cenderung memiliki gizi yang baik dibandingkan dengan anak dengan asupan nutrisi kurang yaitu sebanyak $66,7 \%$. Semua anak dengan asupan nutrisi lebih memiliki status gizi lebih, yaitu sebanyak 3 anak balita (Tabel 6).

Bila status gizi anak balita dibandingkan berdasarkan tingkat pendidikan ibu, maka ibu dengan tingkat pendidikan yang rendah cenderung memiliki anak balita dengan status gizi kurang yakni sebanyak 15,4\%. Begitu pula pada ibu dengan tingkat pendidikan yang tinggi cenderung memiliki anak berstatus gizi baik $(83,8 \%)$. Pada anak yang memiliki status gizi lebih, tingkat pendidikan ibu juga cenderung rendah.

Tabel 6. Distribusi Status Gizi (BB/U) Berdasarkan Faktor Anak Balita dan Ibu

\begin{tabular}{|c|c|c|c|c|}
\hline \multirow{2}{*}{$\begin{array}{l}\text { Variabel } \\
\text { Independen }\end{array}$} & \multicolumn{3}{|c|}{ Status Gizi (BB/U) } & \multirow[t]{2}{*}{ Total } \\
\hline & $\begin{array}{l}\text { Gizi } \\
\text { Kurang }\end{array}$ & $\begin{array}{l}\text { Gizi } \\
\text { Baik }\end{array}$ & $\begin{array}{l}\text { Gizi } \\
\text { Lebih }\end{array}$ & \\
\hline BBL Anak & $6(12,5 \%)$ & 40 & $2(4,2 \%)$ & 48 \\
\hline Normal & $0(0,0 \%)$ & $(83,3 \%)$ & 1 & $(100 \%)$ \\
\hline Lebih & & $\begin{array}{l}1 \\
(50,0 \%)\end{array}$ & $(50,0 \%)$ & $\begin{array}{l}2 \\
(100 \%)\end{array}$ \\
\hline ASI Eksklusif & $4(12,9 \%)$ & 24 & $3(9,7 \%)$ & 31 \\
\hline Tidak & $2(10,5 \%)$ & $(77,4 \%)$ & $0(0,0 \%)$ & $(100 \%)$ \\
\hline $\mathrm{Ya}$ & & $\begin{array}{l}17 \\
(89,5 \%)\end{array}$ & & $\begin{array}{l}19 \\
(100 \%)\end{array}$ \\
\hline Asupan & $5(33,3 \%)$ & 10 & $0(0,0 \%)$ & 15 \\
\hline Nutrisi & $1(3,1 \%)$ & $(66,7 \%)$ & $0(0,0 \%)$ & $(100 \%)$ \\
\hline Kurang & $0(0,0 \%)$ & 31 & 3 & 32 \\
\hline Cukup & & $(96,9 \%)$ & $(100 \%)$ & $(100 \%)$ \\
\hline Lebih & & $0(0,0 \%)$ & & $\begin{array}{l}3 \\
(100 \%)\end{array}$ \\
\hline \multicolumn{5}{|l|}{ Pendidikan } \\
\hline Ibu & $2(15,4 \%)$ & 10 & $1(7,7 \%)$ & 13 \\
\hline Rendah & $4(10,8 \%)$ & $(76,9 \%)$ & $2(5,4 \%)$ & $(100 \%)$ \\
\hline Tinggi & & 31 & & 37 \\
\hline
\end{tabular}

$(83,8 \%)$

$(100 \%)$

\begin{tabular}{|c|c|c|c|c|}
\hline $\begin{array}{l}\text { Pekerjaan } \\
\text { Ibu } \\
\text { Bekerja } \\
\text { Tidak Bekerja }\end{array}$ & $\begin{array}{l}4(12,5 \%) \\
2(11,1 \%)\end{array}$ & $\begin{array}{l}27 \\
(84,4 \%) \\
14 \\
(77,8 \%)\end{array}$ & $\begin{array}{l}1(3,1 \%) \\
2 \\
(11,1 \%)\end{array}$ & $\begin{array}{l}32 \\
(100 \%) \\
18 \\
(100 \%)\end{array}$ \\
\hline Pendapatan & & & & \\
\hline $\begin{array}{l}\text { Keluarga } \\
<\quad \mathrm{Rp}\end{array}$ & $\begin{array}{l}1(4,2 \%) \\
5(19,2 \%)\end{array}$ & $\begin{array}{l}21 \\
(87,5 \%)\end{array}$ & $\begin{array}{l}2(8,3 \%) \\
1(3,8 \%)\end{array}$ & $\begin{array}{l}24 \\
(100 \%)\end{array}$ \\
\hline $\begin{array}{l}1.543 .000 \\
\geq \quad \mathrm{Rp} \\
1.543 .000\end{array}$ & & $\begin{array}{l}20 \\
(76,9 \%)\end{array}$ & & $\begin{array}{l}26 \\
(100 \%)\end{array}$ \\
\hline $\begin{array}{l}\text { Pengetahuan } \\
\text { Ibu } \\
\text { Rendah } \\
\text { Cukup }\end{array}$ & $\begin{array}{l}4(15,4 \%) \\
2(8,3 \%)\end{array}$ & $\begin{array}{l}20 \\
(76,9 \%) \\
21 \\
(87,5 \%)\end{array}$ & $\begin{array}{l}2(7,7 \%) \\
1(4,2 \%)\end{array}$ & $\begin{array}{l}26 \\
(100 \%) \\
24 \\
(100 \%)\end{array}$ \\
\hline
\end{tabular}

Anak balita dengan ibu yang bekerja menghasilkan uang, sebanyak $12,5 \%$ memiliki status gizi kurang daripada ibu yang tidak bekerja memiliki anak balita dengan status gizi kurang sebanyak $11,1 \%$. Begitu pula pada sampel dengan status gizi baik cenderung memiliki ibu yang bekerja (84,4\%) dibandingkan dengan ibu yang tidak bekerja $(77,8 \%)$. Sementara itu pada anak yang berstatus gizi lebih, lebih banyak memiliki ibu yang tidak bekerja $(11,1 \%)$ dibandingkan dengan ibu yang bekerja $(3,1 \%)$.

Apabila status gizi anak balita ditinjau berdasarkan pendapatan di keluarga maka diperoleh hasil bahwa sampel yang pendapatan di keluarganya melebihi UMR ( $\geq$ Rp 1.543.000) cenderung memiliki anak balita yang berstatus gizi kurang dibandingkan dengan pendapatan keluarga yang kurang dari UMR. Sementara pendapatan keluarga yang kurang dari UMR cenderung memiliki anak balita dengan status gizi baik dan lebih.

Berdasarkan data tingkat pengetahuan ibu terhadap gizi, ibu dengan tingkat pengetahuan yang rendah cenderung memiliki anak balita dengan status gizi kurang $(15,4 \%)$ dan lebih $(7,7 \%)$, dibandingkan dengan ibu berpengetahuan cukup (8,3\% gizi kurang dan $4,2 \%$ gizi lebih). Ibu dengan pengetahuan cukup cenderung memiliki anak balita bergizi baik.

\section{PEMBAHASAN}

\section{A. Gambaran Status Gizi Anak}

Menurut Riskesdas RI tahun 2013, prevalensi anak balita yang mengalami gizi kurang secara nasional sebanyak $13,9 \%$ dimana prevalensi gizi kurang di Provinsi Bali sebanyak 9,2\% menurut berat badan dibandingkan umur. Jumlah yang didapat pada penelitian ini ternyata lebih besar dari yang terdeteksi di Bali yaitu sebesar $12 \%$. Hal tersebut dapat disebabkan karena angka kejadian gizi kurang dan buruk di Indonesia tersebar lebih banyak di daerah pedesaan daripada perkotaan yakni diperkirakan sebesar $21 \%$ di desa dan $15 \%$ di perkotaan. Banyak faktor yang dapat mempengaruhi misalnya daya beli masyarakat, harga bahan makanan, jumlah anggota 
keluarga, dan tingkat pendidikan masyarakat pedesaan relatif lebih rendah daripada masyarakat perkotaan. Pihak puskesmas perlu menginformasikan kepada masyarakat mengenai kejadian malnutrisi khususnya gizi kurang pada anak balita serta pola makan yang tepat dan berimbang untuk mencegah terjadinya gizi kurang pada anak balita. ${ }^{6}$

\section{B. Berat Badan Lahir Anak}

Hasil penelitian menunjukkan bahwa hampir seluruhnya lahir dengan berat badan normal yakni sebesar 96\%, sisanya lahir dengan berat badan lebih, dan tidak ditemukan anak yang memiliki berat badan lahir rendah. BBLR bukan merupakan masalah kesehatan masyarakat di wilayah Puskesmas Sukawati I karena prevalensinya di bawah ambang batas yaitu sebanyak 3,2\%. ${ }^{18}$ Namun demikian setiap ada kasus BBLR harus ditangani dengan baik supaya tidak jatuh pada keadaan gizi kurang. Berat badan anak saat lahir sangat berpengaruh bagi perkembangan nutrisi anak. Pada BBLR, kekebalan tubuh kurang sempurna sehingga lebih mudah terkena penyakit infeksi, yang nantinya akan menyebabkan balita kurang nafsu makan sehingga asupan nutrisi berkurang dan dapat menyebabkan gizi kurang. ${ }^{10}$

\section{Riwayat ASı Eksklusif}

Bila ditinjau dari riwayat pemberian ASI eksklusif, lebih dari setengah subjek tidak mendapatkan ASI eksklusif selama 6 bulan awal masa kehidupannya (62\%), sisanya mendapatkan ASI eksklusif. Hal ini sesuai dengan laporan tahunan Puskesmas Sukawati I dimana pencapaian pemberian ASI eksklusif masih rendah di wilayah kerja Puskesmas Sukawati I yakni sebesar $63,3 \% .{ }^{18}$ Cakupan pemberian ASI eksklusif dipengaruhi oleh beberapa hal diantaranya rendahnya pengetahuan ibu dan keluarga lainnya mengenai manfaat dan cara menyusui yang benar, kurangnya pelayanan konseling laktasi dan dukungan dari petugas kesehatan, faktor sosial budaya, kondisi yang kurang memadai bagi para ibu yang bekerja, serta gencarnya pemasaran susu formula. ${ }^{6}$

Pada riwayat pemberian ASI eksklusif di table 6 didapatkan anak balita yang tidak mendapatkan ASI eksklusif cenderung mengalami gizi kurang dibandingkan dengan anak yang mendapatkan ASI eksklusif selama 6 bulan, begitu pula sebaliknya. Hasil penelitian ini sesuai dengan penelitian Anwar dkk (2005) yang menyimpulkan bahwa pendeknya masa ASI eksklusif merupakan faktor risiko kejadian gizi kurang. Air Susu Ibu mempengaruhi kejadian gizi kurang dikarenakan ASI mengandung zat antibodi sehingga balita yang tidak diberikan ASI eksklusif akan rentan terhadap penyakit dan akan berperan langsung terhadap status gizi balita. ${ }^{20}$

Sebagian besar anak yang tidak mendapat ASI eksklusif dikarenakan sudah diberikan susu formula sejak dini. Berat badan pada anak yang mendapat susu formula lebih besar dibandingkan anak yang hanya mendapat $\mathrm{ASI}$, namun hal ini akan menimbulkan risiko terjadinya obesitas. Hasil penelitian ini juga menunjukkan bahwa semua anak bergizi lebih tidak mendapatkan ASI eksklusif sampai 6 bulan (Tabel 6).

\section{Asupan Nutrisi}

Energi rata-rata yang didapat sampel sejumlah 1094 kkal, angka ini masih rendah dibandingkan dengan AKG yang dianjurkan sesuai kelompok umur sampel berdasarkan Widya Karya Pangan dan Gizi Tahun 2013, yaitu 1362,5 kkal per hari. Setelah dilakukan pengelompokan, diperoleh sampel yang mendapat asupan nutrisi $<80 \%$ AKG sebanyak $30 \%$. Kalori merupakan satuan panas dalam proses metabolism dan dipakai untuk menyatakan besarnya energi yang terkandung dalam bahan makanan. Secara umum kalori yang diberikan dimanfaatkan untuk metabolisme basal, SDA (Specific Dynamic Action), aktivitas jasmani, serta eliminasi sisa makanan. Dengan demikian kekurangan asupan kalori mengakibatkan kerja tubuh tidak optimal dan aktivitas hidup akan terganggu.

Berdasarkan analisis bivariat antara status gizi dan asupan nutrisi, didapatkan anak balita dengan asupan nutrisi kurang cenderung mengalami gizi kurang dibandingkan anak dengan asupan nutrisi cukup, begitu pula sebaliknya (Tabel 6). Hal ini sesuai teori dimana kecukupan asupan nutrisi merupakan faktor langsung penentu status gizi anak, selain faktor infeksi pada anak. ${ }^{4}$ Status gizi baik atau status gizi optimal terjadi bila tubuh memperoleh cukup zat-zat gizi yang digunakan secara efisien, sehingga memungkinkan pertumbuhan fisik, perkembangan otak, kemampuan kerja, dan kesehatan secara umum.

Penelitian ini tidak meneliti tentang keragaman jenis makanan yang dikonsumsi oleh balita. Keragaman jenis makanan terdiri dari zat tenaga, zat pembangun, dan zat pengatur. Nutrisi yang menghasilkan zat tenaga adalah karbohidrat dan lemak, protein sebagai zat pembangun, serta yang berfungsi sebagai zat pengatur meliputi vitamin maupun mineral. Keragaman jenis makanan erat hubungannya dengan komoditas daerah dan status ekonomi. Penduduk Indonesia termasuk Bali mengonsumsi makanan pokok berupa nasi.Masih diperlukan pengenalan gizi seimbang, keragaman jenis makanan, serta manfaatnya yang ditujukan pada ibu yang memiliki anak balita untuk membantu dalam menurunkan angka kejadian gizi kurang maupun buruk pada anak balita, khususnya di wilayah kerja Puskesmas Sukawati I.

\section{E. Tingkat Pendidikan Ibu}

Berdasarkan tingkat pendidikan ibu, hasil penelitian menunjukkan bahwa ibu dengan tingkat pendidikan yang rendah sebesar $26 \%$ dan pendidikan yang cukup tinggi sebesar $74 \%$, dengan latar belakang pendidikan terbanyak adalah tamatan SMA 64\%, tamatan SMP sebanyak 14\%, tamatan SD 12\%, serta

http://intisarisainsmedis.weebly.com/ 
ibu yang sekolah sampai bangku perkuliahan sebanyak $10 \%$. Seseorang yang berlatar belakang pendidikan hanya sampai bangku sekolah dasar belum tentu kemampuannya menyusun makanan bergizi terbatas bila dibandingkan dengan ibu yang berpendidikan tinggi. Sekalipun pendidikannya rendah, namun jika orang tersebut rajin mendengarkan penyuluhan gizi bukan sesuatu hal yang mustahil bila pengetahuan gizinya akan lebih baik. Tetap harus dipertimbangkan bahwa faktor tingkat pendidikan turut pula menentukan mudah tidaknya seseorang menyerap dan memahami pengetahuan gizi yang diperoleh. ${ }^{8}$

Berdasarkan Tabel 6 didapatkan anak berstatus gizi kurang cenderung memiliki ibu berpendidikan rendah. Hasil penelitian ini didukung hasil penelitian yang dilakukan Isnansyah (2006), yang menunjukkan adanya pengaruh antara tingkat pendidikan ibu dengan status gizi balita. Temuan dalam penelitian yang dilakukan Imam Hadi (2005) menunjukkan bahwa terdapat hubungan bermakna antara tingkat pendidikan ibu dengan status gizi anak, dimana ibu berlatar pendidikan rendah kemungkinan anaknya berstatus gizi kurang $13 \%$ lebih tinggi dibandingkan ibu yang berpendidikan lebih tinggi.Tingkat pendidikan ibu menjadi prioritas utama untuk mengurangi prevalensi gizi kurang dan terhentinya pertumbuhan pada anak. Hal ini diperkuat dengan penelitian yang dilakukan oleh Sen \& Bharati (2011), menunjukkan bahwa tingkat pendidikan merupakan satu-satunya variabel yang ditemukan yang dapat mempengaruhi gizi anak. Semakin tinggi pendidikan ibu semakin tinggi pula kemampuan ibu untuk menyerap pengetahuan praktis dan pendidikan non formal terutama melalui televisi, koran, radio, dan lain-lain. ${ }^{21}$

\section{F. Pekerjaan Ibu}

Perbandingan antara ibu yang bekerja dan tidak bekerja di Desa Sukawati yaitu lebih banyak ibu balita yang bekerja (64\%). Ibu yang bekerja memiliki waktu yang lebih sedikit untuk memperhatikan dan mengasuh anaknya dibandingkan ibu yang tidak bekerja. Pada umumnya di daerah pedesaan, anak yang kedua orangtuanya bekerja akan diasuh oleh sanak saudaranya sehingga pengawasan terhadap makanan dan kesehatan anak tidak sebaik jika orang tuanya tidak bekerja. Hal inilah yang akan mempengaruhi kualitas waktu dalam hal perawatan anak sehingga akan mempengaruhi status gizi anak. ${ }^{8}$

Hasil penelitian ini menunjukkan kecenderungan bahwa ibu yang bekerja (12,5\%) memiliki anak dengan status gizi kurang dibandingkan dengan ibu yang tidak bekerja (11,1\%). Ibu yang bekerja akan memiliki sedikit waktu untuk perawatan anaknya dibandingkan ibu yang tidak bekerja. Namun, bila dilihat dari anak berstatus gizi baik juga cenderung memiliki ibu yang bekerja dibandingkan ibu yang tidak bekerja. Hasil ini sejalan dengan penelitian Kristanti \& Suriadi (2013), menunjukkan 8 sebagian besar ibu yang bekerja memiliki anak yang berstatus gizi baik.
Hal ini disebabkan adanya faktor lain yang menunjang ibu-ibu yang bekerja memiliki anak berstatus gizi baik yaitu pendapatan keluarga. Keluarga dengan pendapatan lebih kemungkinan besar akan baik dalam memenuhi kebutuhan makanan.

\section{G. Pendapatan Keluarga}

Hasil penelitian menunjukkan sebagian besar pendapatan keluarga per bulan telah melebihi UMR (52\%) dan sisanya di bawah UMR. Tingkat konsumsi zat gizi dipengaruhi ketersediaan makanan yang ditentukan kemampuan atau daya beli keluarga. Rendahnya pendapatan keluarga merupakan halangan yang menyebabkan keridakmampuan membeli pangan dalam jumlah yang dibutuhkan. Anak dalam keluarga miskin paling rentan terhadap gizi kurang. ${ }^{21}$

Apabila status gizi anak balita ditinjau berdasarkan pendapatan keluarga, maka hasil penelitian menunjukkan bahwa pendapatan keluarga yang melebihi UMR cenderung memiliki anak berstatus gizi kurang dibandingkan dengan pendapatan keluarga yang kurang dari UMR. Hasil ini bertentangan dengan penelitian yang dilakukan oleh Patodo (2012), yang menyebutkan bahwa semakin besar pendapatan keluarga maka semakin baik status gizi balita dan begitu pula sebaliknya. Hal ini mungkin disebabkan oleh faktor lain seperti pekerjaan ibu. Ibu yang bekerja akan membantu perekonomian keluarga sehingga pendapatan keluarga akan meningkat. Hasil penelitian ini menunjukkan bahwa pada balita yang pendapatan keluarganya lebih dari UMR cenderung memiliki ibu yang bekerja. Namun di sisi lain, ibu yang bekerja akan kehilangan waktu untuk mengurus anak sehingga pengawasan makanan dan kesehatan anaknya akan berkurang dan memungkinkan anak gizi kurang.

\section{H. Pengetahuan Ibu tentang Gizi}

Pada penelitian ini didapatkan bahwa lebih banyak ibu yang pengetahuannya kurang (52\%) dibandingkan dengan ibu yang berpengetahuan cukup terhadap gizi (48\%) (Tabel 4). Ibu merupakan orang yang berperan penting dalam penentuan konsumsi makanan dalam keluarga khususnya pada anak balita. Kurangnya pengetahuan ibu tentang gizi menyebabkan keanekaragaman makanan menjadi berkurang. Selain itu, gangguan gizi juga disebabkan oleh kurangnya kemampuan ibu menerapkan informasi tentang gizi dalam kehidupan sehari-hari. ${ }^{14}$

Pada anak balita yang mengalami gizi kurang di Desa Sukawati, cenderung memiliki ibu dengan tingkat pengetahuan gizi yang kurang (15,4\%) dibandingkan dengan ibu berpengetahuan cukup mengenai gizi (8,3\%) (Tabel 6). Hasil penelitian ini sejalan dengan hasil penelitian yang dilakukan oleh Patodo (2012) yang menunjukkan pengetahuan ibu berpengaruh terhadap status gizi anak. Hal ini diperkuat dengan hasil penelitian yang dilakukan oleh Permana (2011) yang menunjukkan bahwa pengetahuan gizi merupakan faktor yang berhubungan dengan status gizi kurang pada balita. 
Pengetahuan ibu tentang gizi sangat berpengaruh terhadap tingkat kecukupan gizi yang diperoleh oleh anak balita. Pengetahuan tentang gizi yang penting diketahui oleh ibu adalah berkaitan dengan kandungan makanan, cara pengolahan makanan, kebersihan makanan dan lain-lain. Perilaku yang didasari pengetahuan bersifat lebih langgeng daripada perilaku yang tidak didasari pengetahuan yang baik. Sehingga pengetahuan yang baik akan membantu ibu atau orangtua dalam menerapkan perilaku hidup sehat seperti pemilihan kualitas dan kuantitas makanan. ${ }^{14}$

\section{Kelemahan Penelitian}

Kelemahan dalam penelitian ini diantaranya populasi sampel yang terbatas pada anak balita berusia 6-59 bulan, jadi penelitian ini kehilangan data status gizi anak balita usia 0-6 bulan maupun gambaran faktor risiko yang terkait. Selain itu pada penelitian ini mungkin tidak sepenuhnya mencerminkan perilaku ibu balita yang sebenarnya, dapat disebabkan adanya kemungkinan responden tidak berkata jujur saat wawancara.

\section{SIMPULAN}

1. Distribusi frekuensi karakteristik demografi subjek, menurut usia ibu didominasi oleh ibu yang berusia 25-35 tahun (60\%) dengan rerata usia yaitu 33 tahun. Sementara itu, rerata usia anak yang menjadi subjek penelitian yaitu 29 bulan dan sebagian besar berjenis kelamin laki-laki.

2. Distribusi frekuensi faktor risiko gizi kurang ditemukan $96 \%$ anak dengan berat badan lahir normal, $62 \%$ balita yang tidak mendapatkan ASI eksklusif, $30 \%$ balita dengan asupan nutrisi kurang, 26\% balita yang memiliki ibu dengan tingkat pendidikan rendah, $64 \%$ balita dengan ibu yang bekerja, $48 \%$ balita dengan pendapatan keluarga rendah, serta sebanyak $52 \%$ balita memiliki ibu dengan pengetahuan terhadap gizi yang kurang.

3. Status gizi berdasarkan $B B / U$ terdapat $12 \%$ anak bergizi kurang, berdasarkan BB/TB sebanyak $8 \%$ anak sangat kurus dan $12 \%$ anak kurus, menurut $\mathrm{TB} / \mathrm{U}$ sebesar $8 \%$ anak bertubuh sangat pendek serta $6 \%$ bertubuh pendek.

4. Faktor risiko yang cenderung terjadi pada anak balita yang berstatus gizi kurang di Desa Sukawati yakni tidak mendapat ASI eksklusif selama 6 bulan, asupan nutrisi kurang, pendidikan ibu yang rendah, balita yang memiliki ibu bekerja, serta

\section{SARAN} tingkat pengetahuan ibu tentang gizi yang rendah.

1. Puskesmas disarankan meningkatkan program gizi anak balita dalam upaya pencegahan terjadinya malnutrisi, penemuan kasus malnutrisi pada anak balita serta manajemen dini. Pihak puskesmas perlu menginformasikan kepada masyarakat mengenai malnutrisi khususnya gizi kurang pada anak balita serta pola makan yang tepat dan berimbang untuk mencegah terjadinya gizi kurang pada anak balita.

2. Jumlah makanan yang dikonsumsi cukup, tetapi masih diperlukan pengenalan gizi seimbang, keragaman makanan, dan manfaatnya yang ditujukan pada ibu yang memiliki anak balita untuk membantu dalam menurunkan angka kejadian gizi kurang maupun buruk pada anak balita, khususnya di wilayah kerja Puskesmas Sukawati I.

\section{DAFTAR PUSTAKA}

1. Aritonang, I. (2003), Pemantauan Pertumbuhan Balita, Kanisius, Yogyakarta.

2. Azreen, S. (2004), "Breast-Feeding and Child Obesity - A Systemic Review", International Journal of Obesity, pp. 1247-1256.

3. Badan Penelitian dan Pengembangan Kesehatan Departemen Kesehatan RI. Laporan Nasional Riset Kesehatan Dasar (Riskesdas) 2013, Christien, I. (2007), Asupan Energi Protein, Status Gizi, dan Prestasi Belajar Anak Sekolah Dasar Arjowinangun I Pacitan, Universitas Gajah Mada, Yogyakarta.

4. Daniel, S. (2009), “Complications of Obesity in Children and Adolescents", International Journal of Obesity, vol. 33, no. 1, pp. 60-65.

5. Departemen Kesehatan RI. (2011, January 20 last update), "Terapkan 10 Langkah Menuju Keberhasilan Menyusui”, (Depkes RI), Available: http://www.depkes.go.id/index.php/berita/1167terapkan-10langkahmenuju-keberhasilanmenyusui.html (Accessed: 2014, December 7).

6. Hadi, I. (2005), Beban Ganda Masalah Gizi dan Implikasinya terhadap Kebijakan Pembangunan Kesehatan Nasional, Pidato Pengukuhan Jabatan Guru Besar Fakultas Kedokteran Universitas Gadjah Mada, Yogyakarta.

7. Johanis, A., Aaltje, E. (2011), Hubungan Tingkat Sosial Ekonomi dengan Kurang Energi Kronik Pada Ibu Hamil di Kelurahan Kombbos Barat Kecamatan Singkil Kota Manado, Univ Samratulangi, Manado.

8. Kartika. (2002), Faktor Yang Mempengaruhi Status Gizi Anak, FK Universitas Indonesia, Jakarta.

9. Kosim \& Sholeh, M. (2008), Buku Ajar Neonatologi Edisi I, Badan Penerbit IDAI, Jakarta.

10. Kurniawati,E.(2011), “Hubungan Pengetahuan Ibu Tentang Gizi Dengan Status Gizi Balita di Kelurahan Baledono, Kecamatan Purworejo", Journal Komunikasi Kesehatan, vol. 3, no. 2.

11. Kusharto \& Sa'adiyah. (2006), Diktat Penilaian Konsumsi Pangan, IPB Press, Bogor.

12. Mardiarti, E. (2000), Gambaran Status Gizi Anak Balita ditinjau dari Pola Pengasuhan Pada Ibu Bekerja dan Ibu Bukan Pekerja. Universitas Sumatera Utara, Medan. 
13. Notoatmodjo S. (2003), Prinsip-Prinsip Dasar IImu Kesehatan Masyarakat, Rineka Cipta, Jakarta.

14. Nurmiati. (2006), Pertumbuhan Perkembangan Anak Balita dengan Status Gizi Stunting dan Normal. Fakultas Pertanian IPB, Bogor.

15. Permana, W.E. (2011), Analisis faktor-faktor yang mempengaruhi status gizi kurang pada balita di Wilayah Kerja Puskesmas Baturaden II. (Skripsi), Universitas Jenderal Soedirman, Purwokerto.

16. Patodo, S. (2012), Faktor berhubungan dengan status gizi balita di Wilayah Kerja Puskesmas Wawonasa Kota Manado, UNSRAT, Manado.

17. Puskesmas Sukawati I. (2013), Laporan tahunan Puskesmas Sukawati I tahun 2013, Departemen Kesehatan, Gianyar.

18. Santosa. (2004), Kesehatan dan Gizi Anak, Rineka Cipta, Jakarta.

19. Soekirman. (2000), Ilmu Gizi dan Aplikasinya untuk Keluarga dan Masyarakat, EGC, Jakarta.

20. Suhardjo. (2005), Perencanaan pangan dan gizi, Bumi Aksara, Jakarta.

21. Supariasa, dkk. (2002), Penilaian Status Gizi. Penerbit Kedokteran EGC, Jakarta.

22. WHO. (2012), "Nutrition Experts Take Action on Malnutrition", (WHO), Available: http://www.who.int/nutrition/pressnote action_on_malnutrition/en/index.html (Accessed: 2014, November 30).

23. Webber, R. (2005), Communicable Disease Epidemiology and Control a Global Perspective, 2nd ed, CABI Publishing, UK.

24. Yussac, Aristato, dkk. (2007), "Prevalensi obesitas pada anak usia 4-6 tahun dan hubungannya dengan asupan dan pola makan", Majalah kedokteran Indonesia, vol. 57, no. 2. 